\title{
Making Sense of the Anti-Same-Sex-Marriage Movement in France \\ Scott Gunther
}

["Making Sense of the Anti-same-sex-marriage Movement in France," French Politics, Culture and Society, summer 2019, Volume 37, Issue 2]

\begin{abstract}
This article examines the political style and rhetoric of the Manif pour tous (MPT), the main organization opposing same-sex marriage in France, from summer 2013 to the present. It exposes how the MPT's style and rhetoric differ from those of their American counterparts, and what this tells us about the different strategies of political movements in France and the United States generally. It is based on an analysis of the language used by activists whom I interviewed in 2014 and 2015 and on a discourse analysis of the MPT's website, Facebook page, Twitter feed, and press releases since 2013. This analysis of the distinctive features of the MPT brings to light underlying concerns about French identity in the face of globalization. In other words, for the MPT and its members, what is at stake is not just same-sex marriage but the very definition of Frenchness.
\end{abstract}

Keywords: filiation, GLBTQ politics, laïcité, Manif pour tous, national identity, same-sex marriage, théorie du genre, universalism 


\section{Making Sense of the Anti-Same-Sex-Marriage Movement in France ${ }^{1}$}

\section{Figure 1.}

In February 2013, the French National Assembly passed a bill to allow same-sex couples to marry and adopt children; the Senate eventually approved the bill in June. The issue remains far from settled, however. In the years following the Senate's decision, France has witnessed a series of anti-same-sex-marriage demonstrations, organized primarily by the umbrella organization La Manif pour tous (the "protest for everyone") or MPT, calling on the government to reconsider its decision. $^{2}$

This article examines the rhetoric of the French anti-same-sex-marriage movement, primarily that of the MPT, which will serve as a prism through which broader features of the French political context will become more apparent, features that encourage rhetorical strategies different from what would be expected in the US. This article focuses on the situation in France and does not aim to give equal treatment to the French and American contexts. It is comparative only in the sense that I am American and prone to notice those elements of the French anti-samesex-marriage movement that are different from what I have come to expect in the US. I argue that each of the distinctive features of the French context points to a particular concern over the definition of Frenchness in an increasingly globalized world. I also argue that among the differences between the French and US contexts listed below, most striking is the absence of religious rhetoric in the French context. This absence signals that French secularism (or laïcité), 
which the political left originally used to limit the influence of Catholicism, has become a core value for the political right as laïcité has increasingly become a tool for regulating Islam alone.

The rhetoric analyzed here comes from several different sources, including official statements made by MPT leaders in the press; on its website, Facebook page and Twitter account; and in personal interviews I conducted in the summers of 2014 and 2015. In addition, I consider less official statements made by anyone who chose to leave comments on the MPT's Facebook page or Twitter feed. Gaining access to the MPT and obtaining interviews with its members was challenging. I began by contacting the group directly and asking whether anyone would be willing to meet with me. These efforts were entirely unsuccessful. Finally, a French acquaintance of mine told me that he knew somebody who is active in the MPT. The personal connection proved to be essential to establishing trust, and this is how I made my first contact. At the end of this first interview and the interviews that followed, I asked each interviewee whether he or she would be willing to introduce me to anyone else. This method, commonly referred to as "snowball sampling," has both disadvantages (the sample may not be representative, as it lacks randomness) and advantages (it helps provide access to groups that might be less open to the idea of being interviewed). There is a deep distrust of outsiders and of the mainstream media among members of the anti-same-sex-marriage movement, based on the belief that their statements are frequently distorted in the press. For three of the interviews, a member of the group asked to stand nearby and make his own recording, so that he could later verify any quotes that I included in this article, and I agreed that I would send him the quotes for him to confirm before submitting this article for publication. In the end, I was able to conduct a total of seven interviews (six men, one woman) with participants in the actions of the MPT as well as in the actions of subgroups included under the MPT's umbrella, such as the Veilleurs (the watchmen) or the Sentinelles (the 
sentinels). I recorded and transcribed each interview (the translations from French to English are my own) and created pseudonyms to preserve the anonymity of the interviewees. The interviewees knew I was American and gay, which could have influenced how they spoke to me. For example, they may have provided me with more contextual information than they would have with a fellow French person. They may have also been less likely to express homophobic views. I was recording them and they knew that their statements could appear in a journal, so at no point was their guard down. They were aware that people not necessarily sympathetic to the cause would be reading their comments and that they should aim to portray the movement in a positive light.

Unlike France, where a single umbrella organization, the MPT, is the main source of opposition to same-sex marriage, the United States has many separate groups. The most influential groups have been the Family Research Council, the American Family Association, and the Concerned Women for America. These American groups share many features. They all see same-sex marriage as a menace to the "sanctity" of traditional heterosexual marriage. They are all concerned about the possibility of children being "recruited" by adult gays and lesbians. They are all also fighting for an array of issues besides same-sex marriage, and while some issues are specific to just one group, all overlap in their opposition to abortion, sexual promiscuity, and pornography; and in their support for sexual abstinence before marriage, a stronger role for parents in their children's education, and the protection of religious freedom. ${ }^{3}$ Finally, as is apparent in all of their mission statements, religious beliefs are central: the Family Research Council's mission is "to advance faith, family and freedom in public policy and the culture from a Christian worldview"; ; for the American Family Association, it is "to inform, equip, and activate individuals to strengthen the moral foundations of American culture ... AFA 
believes that a culture based on biblical truth best serves the well-being of our nation and our families"; and for the Concerned Women for America, it is "to protect and promote Biblical values among all citizens—-first through prayer, then education, and finally by influencing our society - thereby reversing the decline in moral values in our nation." Accordingly, much of their opposition to same-sex marriage stems from disapproval of sexual activity between people of the same sex, which they consider sinful. These various features of the anti-same-sex movement in the US are apparent in the word cloud below, which shows the most common words appearing in tweets sent from and to the Family Research Council, and where the size of the word correlates to the frequency with which it appeared.

\section{FIGURE 2}

The word cloud for the MPT points to some of the fundamental differences between the rhetoric in France and the United States with regard to same-sex marriage, where the most frequent terms include "GPA" ("gestation pour autrui," or surrogate motherhood), "enfant(s)" (child/children), "Taubira" (Christiane Taubira was the Minister of Justice who defended the same-sex marriage law), "adoption," and "PMA" ("procréation médicalement assistée," or medically assisted procreation). ${ }^{7}$

\section{FIGURE 3}

The distinctive features of the rhetoric of French groups opposing same-sex marriage stand in sharp contrast to those of their American counterparts. These features fall into six categories: first, while it has been common in the US for groups to talk about the "sanctity of marriage," in France the opposition has been framed more in terms of what might be referred to as the "sanctity of filiation"; second, in France, the concern for children is not about their possibly being "recruited" by gay adults, but about the erosion of traditional gender roles in 
children growing up with same-sex parents; third, while American opposition to same-sex marriage has little difficulty identifying itself as Christian, heterosexual, and politically on the right, French opponents have insisted that they are areligious, composed of both gay and straight people, and neither on the left nor the right politically; fourth, the protests against same-sex marriage in France have appeared much more festive than their counterparts in the US; fifth, while in the US there is overlap between opposition to same-sex marriage and opposition to issues such as abortion and sexual promiscuity, in France the overlap is with opposition to expanding access to medically assisted procreation and surrogacy, which are represented as improper meddling with nature, or sometimes, as consequences of unbridled neoliberalism; and most importantly, sixth, while arguments against same-sex marriage in the US have often relied on a religiously inspired criticism of homosexual acts per se, in France, members of the MPT have insisted that their opposition to same-sex marriage is in no way a criticism of homosexuality and has nothing to do with religion.

The following six sections will examine these categories one by one, starting in each case with examples of rhetoric from the French context that illustrate the differences between French and US opposition to same-sex marriage, followed by an analysis of how these differences point to distinctive features of the French political context. As we will see, the difference between US and French rhetoric points to broader concerns about French identity in the face of globalization. In other words, for the MPT and its members, what is at stake is not just same-sex marriage but the definition of Frenchness.

This project builds on the work of Bruno Perreau (who has examined the reception of socalled "gender theory" in France ${ }^{8}$ ), Camille Robcis (who has analyzed the use of Republican iconography in protests against same-sex marriage ${ }^{9}$ ), and Eric Fassin (who has written about 
concerns over filiation in discussions about same-sex parenting ${ }^{10}$ ) and recognizes a common thread among all three: namely, that in each case the central concern is what it means to be French in an increasingly globalized world. By highlighting a preoccupation with national identity, their work served as a springboard for me to consider how looking for signs of concern over the definition of Frenchness could be useful in explaining other features of the French antisame-sex-movement.

\section{Concern for the "Sanctity of Filiation" rather than the "Sanctity of Marriage"}

\section{Figure 4}

Leaders of the MPT insist that they are not against legal recognition of same-sex couples. Civil union (the Pacte civil de solidarité, or PACS) has been open to both same-sex couples and opposite-sex couples in France since 1999, so most people consider the question of whether same-sex couples should be legally recognized to be settled. One informant, François, explained: "I didn't protest against the PACS. It didn’t bother me."

A PACS confers many but not all of the same rights as marriage, the most notable differences being that the PACS does not allow couples to adopt children jointly, inheritance from a deceased partner is not automatic, and pensions from a deceased partner are not transferred to the surviving partner. Xavier Bongibault, an openly gay MPT activist, thinks that same-sex couples just need an improved form of the PACS rather than marriage. In particular, he would like to see a new structure that "would guarantee equality for tax purposes and for inheritance issues." ${ }^{11}$ Similarly, Laurence Tcheng, one of the movement's most visible socialist 
members, is "more in favor of a civil union ... that grants the same rights with respect to property, pensions from deceased spouses, alimony in case of separation, etc."12

Another relevant difference between the French and American contexts is that in France, religious marriage ceremonies are distinct from civil marriage ceremonies. Unlike the US, where a single religious ceremony can serve a double function, France requires a religious ceremony for a couple's marriage to be recognized by the church and a civil ceremony for a couple's marriage to be recognized by the state. This explains the bifurcated response of a retired priest who is also mayor of the village of Eréac in Brittany, and who has said that once the law passed in the Senate he would happily perform same-sex marriages in his town's city hall, but would not be performing religious ceremonies for those same couples in the church down the street. ${ }^{13}$ The separation of the civil from the religious encourages people to envision these two kinds of marriage as distinct, and has made the same-sex marriage bill, which only deals with civil marriage, seem like less of a religious issue than it would in a country like the US where the boundaries between civil and religious marriages are blurred.

A third difference is that people are less likely to refer to the "sanctity of marriage" in a country like France where fewer and fewer people are interested in the institution, with the rate falling from 7.8 marriages per 1,000 people in 1970 to just 3.7 per 1,000 in 2012 (compared to 6.8 per 1,000 people in the US in 2011). ${ }^{14}$ Even the former leader of the extreme-right National Front party, Jean-Marie Le Pen, said that he had no issue with legal recognition of same-sex couples, because it serves to bolster the institution of marriage: "The fact that there are men who love each other, after all why not? ... The fact that men wish to sanctify their unions in a secular fashion proves that marriage is regaining a prestige that we feared it had lost." 15 
For MPT activists, the primary motivation for opposing same-sex marriage is that it would grant same-sex couples the right to adopt. Their opinions are reflected in comments from the people I interviewed.

"Well, the concept of gay marriage didn't bother French people. Adoption, on the other hand, did." (Philippe)

"Now ... everyone has the right to adopt. That's why we, well, me personally, I started to fight against this, it wasn't marriage itself that was a problem.” (Julie) Consequently, as opposed to being concerned about the sanctity of marriage, the opposition to same-sex marriage in France has focused on what might be called the "sanctity of filiation.” Sociologist Eric Fassin explains that:

This French controversy stands the American polemic over 'gay marriage' on its head. In the United States, 'sacralization' focuses on marriage itself, while gays and lesbians often encounter relative indifference when it comes to adoption and reproductive technologies. ${ }^{16}$

Fassin goes on to explain this difference between the US and France by arguing that concerns over filiation are linked to concerns over racial purity in contemporary France. For him, in contemporary representations of the nation in France, there is an obsession with 'origins,' 'roots,' and 'stock;' in a word, with 'blood.' It is manifest in the language itself, whether talking about Français de souche (people with French ancestry) or conversely Français de papier, issus de l'immigration (people who are French on paper, of immigrant descent).... Indeed, the French battle about kinship is not simply about the family; it is as much about the nation. Naturalizing filiation (as conservatives would have it), or denaturalizing it (in progressive terms), is not just about 
heterosexuality or homosexuality; it is equally about Frenchness, that is, about whiteness in postcolonial France. ${ }^{17}$

\section{Protecting Children from "Gender Theory"}

\section{Figure 5.}

A major concern among opponents is the fear that same-sex marriage may lead to an erosion of gender roles. Gender roles are important in France and the notion of essential sexual difference runs deep even among some strands of feminism, particularly those associated with the theoreticians Luce Irigaray and Hélène Cixous. In the summer of 2011, after it had been announced that high school sex-education textbooks would begin to discuss gender roles as "socially constructed," eighty députés from the National Assembly and 114 senators—-that is,

roughly one third of all senators - sent letters of protest to the minister of education. ${ }^{18}$ Opponents of these curricular changes labeled the new program "gender theory" (théorie du genre). This terminology was common in statements from my informants. Philippe said that "gender theory, from the beginning of the protest, it was there," and François explained that "gender theory is very insidious."

Opponents circulated exaggerated claims and false rumors of what "gender theory" was doing to France's school children, including leading them to precocious sexual promiscuity, encouraging them to become genderless beings, and instructing them on how to masturbate at a 
very young age. ${ }^{19}$ Supporters of the reform pointed out that there is no such thing as gender theory; they argued instead that gender is merely a concept, a useful term for referring to the social construction of masculinity and femininity. ${ }^{20}$ It is consequently not surprising that in the text of the current bill for same-sex marriage, one of the most contested elements seems to have been the idea of replacing the words "father" and "mother" throughout the Civil Code with the word "parent," which appeared in the original bill but was dropped for the final version made law. ${ }^{21}$

The alleged threat that same-sex marriage poses to traditional gender roles is based on the notion that without parents of different sexes, children will not have gender models to follow. Emmanuel, an MPT activist, explained, "one dad and one mom. We cannot deprive a child of the balance he needs."22 Another informant, Marc, said, "I'm not necessarily fighting against the Taubira Law today, what bothers me is the children.... It disturbs me for children to be raised by two men or two women, even more when it's two men."

At the same time, the fact that "gender theory" is being taught in schools will lead to a greater acceptance of homosexuality and to more same-sex marriages. In other words, as Camille Robcis has pointed out, "the 'theory of gender' ...emerges as both the cause and the outcome of gay marriage. If homosexuals are allowed to reproduce, who will emerge from this process? What will the family look like, and more importantly, what will the future, the social, and the nation look like? Likewise, if children are taught to question gender stereotypes and to think about their sexual identity as more fluid with the help of this 'theory of gender,' what kind of citizens will they become? What norms will govern our world?"23

In addition, the fact that the debate centers on the content of school textbooks taps into a long-standing Catholic anxiety of the state controlling education, which can be traced back at 
least to the Third Republic. In the 1880s, the expansion of the role of private religious schools came to an end, first with "the decision to open a normal school in each département over a fiveyear period (law of 9 August 1879), the institution of free, secular, and obligatory primary education (laws of 16 June 1881 and 28 March 1882) and the secularization of school personnel (law of 30 October 1886)." ${ }^{24}$ Catholics have been concerned since that time about schools' disturbing traditional family roles. They were against free education, for example, "because it would deprive the father of the recognition from his children of the financial sacrifice he accepted for their education.... Attached to a hierarchical conception of society, Catholic leaders emphasized the importance of paternal authority as a model for just social relations." ${ }^{25}$ One informant, Julie, put it this way: "The problem is that currently the government wants ... to take child-raising away from the parents and entrust it to the state. And consequently, through schools, they especially want to teach children gender theory and want to try to get them to understand from the beginning: 'You're not a girl and you're not boy. You have the right to choose your sex. You will choose later."

Several informants made a point of telling me that "gender theory" was imported from America:

“'Gender theory,' which comes from the United States by the way, claims that a child isn't born a man or a woman, but becomes one by way of family and societal influences.” (Pierre)

"Gender studies [he said "gender studies" in English] ... doesn't hold up.... As much as I might think in my mind, I want to be a woman, no, physically I remain a man. That is a reality that imposes itself." (François) 
François was not the only one to use the untranslated English word "gender" in referring to these ideas, which serves to emphasize its alleged foreign origins. Indeed, an important aspect of the opposition to "gender theory" is its supposed American roots. As Bruno Perreau has explained:

Its detractors claim that "gender theory" was invented in the United States, a society built on a consumerist, communitarian, and politically correct model, hence fundamentally incompatible with France's own traditions of intercourse between the sexes. ${ }^{26}$

The American referent in discussions of "gender theory" is useful as a means of discrediting it. As a number of recent works have pointed out, the use of "America" in France has generally been more of a rhetorical strategy than a reflection of reality, since "America" is a word that can be filled with many different meanings, or, to borrow the terminology of LeviStrauss, "America" is a floating signifier. With regard to the use of "America" in discussions of gender and sexuality in France during the 1990s, Eric Fassin referred to the rhetorical strategy of the American "scarecrow," such that by associating one side of a debate with the "American position," it becomes impossible to agree with it without being suspected of betraying France. ${ }^{27}$ This was especially the case when discussing issues of gender or sexuality. Fassin explained that "in the same way that one could say in the United Sates that communism is 'un-American,' in France, sexual politics seem 'un-French,' to the benefit of diatribes against 'political correctness. ${ }^{\prime 28}$

To illustrate the use of the American scarecrow, Fassin provided the example of how anti-Americanism has fueled antifeminism in France: "the [French] rhetorical strategy of associating feminism with [American] puritanism is telling: in France, people see any 
politicizing of sexuality as a product of moralism à l'américaine, something foreign to French culture, which we like to believe is more 'sophisticated."' Writing about the 2000 law on parité that sought to increase the representation of women in political offices, for example, the French essayist Elisabeth Badinter denounced "American-style quotas" - a clear example of the American scarecrow, since quotas are not even allowed in the US for affirmative action purposes. ${ }^{29}$ With regard to homosexuality, Frédéric Martel's 1996 book Le Rose et le Noir concluded that French gays and lesbians should embrace the French republican model of assimilation and reject American-style identity politics. The former he associated with the French model of social integration, and the latter with American-style "ghettoization" of minorities. ${ }^{30}$ Fassin's description of the use of the American scarecrow in the 1990s is still pertinent today, this time through its potency in discrediting the idea that gender is socially constructed. Moreover, the American referent is a sign that what is actually at stake in these discussions over "gender theory" is a definition of Frenchness. As Nicole stated at an MPT rally: "I have been present at all the protests opposing ... gender theory. I have come to defend my culture." ${ }^{\prime 1}$

\section{Broad Participation (Left/Right, Gay/Straight) in the MPT}

\section{Figure 6.}


The MPT represents itself publicly as an apolitical organization, made up of people from across the political spectrum - hence the "pour tous" ("for everyone") in the group's name. Statements from the people I interviewed reflected this idea:

“There's really everything here.... There are people from the Left and the Right. There is also a homosexual group that fought against the law for same-sex marriage.... They have a rainbow flag and yes, there are homosexuals who say no." (Pierre)

"Listen, it's true that there might be a lot of Catholics among us, some of whom are practicing. It's true, but that said, there's a bit of everything. There's even, you might see him, there's even a Jew here today in religious clothing. You've got everything.... Since we're not at all organized, we don't necessarily have the same ideas, so there are all different perspectives here.” (Marc)

To support the claim that the group has a diverse range of participants, Frigide Barjot, one of the former leaders of the MPT, described the group's leadership this way: “There's the left-winger, the gay guy, and the Catholic." ${ }^{32}$ The "left winger" is Laurence Tcheng, founder of "The Left for Republican Marriage." The "gay one" is Xavier Bongibault, from the group "Gayer without marriage," who "spends the whole day denouncing 'the homophobia of LGBT associations and of the government,' which take away gay individuals' 'freedom of speech."'33 Barjot herself is "the Catholic" and a self-proclaimed "“wacko' for God, admirer of Benedict XVI." ${ }^{34}$ She is the "polar-opposite image of the austere Christine Boutin, muse of the anti-PACS movement," and "avoids coming across as uptight [by riding] a pink scooter, and always [wearing] a jacket that bears the inscription of a famous gay Parisian bar." 35 Indeed, before taking on her role in the MPT, she was a well-known figure in the Parisian gay cabaret scene. 
This strategy of presenting a political movement as non-sectarian is not at all unique to the MPT. In France, social movements generally avoid presenting themselves as advocating for particular demographic groups, lest they be accused of engaging in American-style identity politics. Indeed, before the MPT came into existence, supporters of the law legalizing same-sex marriage also opted for universalist language, by labeling the proposed legal reform "marriage for everyone" in order to present it not as something for a specific group, but as a means of remedying the non-universalist marriage law that did not treat everyone the same. Supporters of the PACS in the 1990s also employed this strategy when they proposed a civil union that would be open to any couple — heterosexual or homosexual—and thus avoided accusations of creating a legal category for a specific group. ${ }^{36}$

The notion that French political demands should be presented in universal, non-sectarian terms is one of the core values of the French Republic. Consequently, through the MPT's commitment to the discourse of universalism, it is clear that this movement cannot be characterized as part of a tradition of right-wing anti-republicanism as some have assertedthough its claim of being apolitical is more of a response to French universalism than a reflection of reality. (Typically an MPT protest is attended by supporters of the "rightist UMP party, the [nationalist] National Front, and all the other constellations of the far-right." ${ }^{37}$ )

The group's commitment to Republican values is further evident in the use of explicit republican iconography during the MPT's protests. (At one protest, a group of women dressed up as Mariannes wielding copies of the French Civil Code.) As Camille Robcis has pointed out, these references do not "evoke a leftist tradition only. These have also all functioned as symbols of French republicanism, and more generally, of France.... The re-appropriation of republican imagery on the part of the anti-gay-marriage movement was thus not a coincidence, a parody, a 
misunderstanding of French history, an act of political cynicism, or a simple displacement of economic anxieties. ${ }^{38}$ It is another sign that what is actually at stake in the debate over gay marriage is the definition of Frenchness.

\section{Light-Hearted and Playful Protest Style}

\section{Figure 7.}

The agitators borrow the shock tactics or playful gimmicks of Act Up, the naked bodies of the Femen, the bright colors of the "Velvet Revolution." 39

The protest styles of the anti-same-sex-marriage movement in France have been different enough from their American counterparts to receive media attention in the United States. On the Colbert Report after showing a clip of MPT protestors, Stephen Colbert said "[just] to be clear, in France, the people with the pink signs dancing to ABBA ... are the anti-gay protestors. ${ }^{\circ 0}$ On the Daily Show, John Oliver had a similar take on the protests when he asked, "Quick question, how is it that France's anti-gay protests look so much gayer than our pro-gay protests?" Oliver then showed a clip of a protest by a member of the anti-same-sex marriage group, the Hommen, ${ }^{41}$ during the French Open, and said: "Listen, I don't want to be in the position of giving tips to bigoted, anti-gay forces, but just in terms of pure message discipline, you might want to go with something that doesn't so much scream 'audition piece for Cirque de Soleil." ${ }^{\text {"42 }}$ Oliver's comparison with the cirque de Soleil may have been more insightful than he realized, since much 
of the style of these protests is borrowed more or less explicitly from leftist protests of the twentieth century, including the Situationist-inspired protests during the widespread revolts of May 1968 and their carnivalesque aesthetics, something Claire Tancons labeled "Carnival liberation theory." 43 For Nicolas Truong, the events of May '68 serve as clear inspiration for the MPT protests of May 2013:

The desire to reappropriate or to recuperate thinkers from May '68, like the Situationist, Guy Debord (1931-1994), often cited by the movement's apologues, is obvious. One can even sense the desire to write a De la misère en milieu croyant (On the Poverty of the Believer's Life) [the original situationist book was titled De la misère en milieu étudiant (On the Poverty of Student Life)]. ${ }^{44}$

The French Situationist Raoul Vaneigem wrote that "a strike for higher wages or a rowdy demonstration can awaken the carnival spirit," and "revolutionary moments are carnivals in which the individual life celebrates its unification with a regenerated society." 45 The joyful, ludic style of French street activism continues to be a feature of French protests today, as witnessed by the techno-fueled dances of the spring 2016 Nuit Debout movement or almost any public political action by French labor unions. ${ }^{46}$ It is less common to see a politically conservative movement appropriate this aesthetic, but the MPT has apparently recognized the value of showing the "modernity of the defended cause" by looking more like a party than a religious march. ${ }^{47}$ Its protest styles stem from the desire both to avoid being seen as sectarian, which could happen if it came across as overly conservative, and to anchor itself in an aesthetic that can claim French origins. This playful protest style is once again an assertion of what it means to be French. 


\section{Issues Beyond Same-Sex Marriage}

\section{Figure 8.}

In the United States, the principal anti-same-sex-marriage groups are concerned with issues beyond same-sex marriage, most importantly the issue of abortion. Though the MPT is not concerned with abortion, it does have its own concerns that are somewhat peripheral to same-sex marriage, namely: medically assisted procreation, typically in the form of artificial insemination; and surrogate motherhood. The MPT calls for French resistance to the increased availability of medically assisted procreation and the legalization of surrogate motherhood. In one respect, this call is made in environmental terms by relying on the notion of "human ecology"; in another respect, the MPT evokes the dangers posed by unbridled capitalism, including the idea that these technologies would transform children into mere commodities. Indeed, some of their posters show images of children with bar codes around them or of shopping carts, with slogans like "Women are not baby machines"; "A human being is not a commodity"; and "A child is priceless." 48

The opposition to medically assisted procreation is often framed in ecological terms as the need for French resistance to the potential danger of meddling with nature. The strategy of framing the debate in terms of defending or opposing "human ecology" was developed by Pope Benedict XVI, who compared the protection of traditional gender roles to the protection of the rain forests. ${ }^{49}$ The political philosopher Chantal Delsol explains that "among the many 
disgruntled individuals making up the numerous Manif pour tous demonstrations, there is a faction made up of a new type of ecologist: these are ecologists of humanity as much as of nature." ${ }^{50}$ One of my informants, Xavier, expects the issue of human ecology to become central to the French political arena, because "the opposition between the Left and the Right is disappearing.... It will be replaced by an opposition between 'transhumanists' [who believe it is acceptable to meddle with nature] and 'bio-conservatives' [like the members of the MPT who do not think it is acceptable]."

All of the informants were more troubled by the issue of surrogate motherhood than the issue of medically assisted procreation. Their arguments tended to rely on concerns over the place of human beings in an increasingly globalized, neo-liberal economy. Michael StambolisRuhstorfer and Josselin Tricou have pointed out that French Catholics are now split between what might be referred to as "identity-based" Catholics who "foreground ... the Judeo-Christian origins of Europe, regret cultural pluralism and have some affinities for nationalistic right-wing political currents" and those who have been concerned primarily with issues of social and economic justice. ${ }^{51}$ These new ecologists stem from the latter, such that their "human ecology" arguments are mixed with worries over unbridled capitalism.

"I have been present at all the marches and I am passionately opposed to surrogate motherhood. I see it as opening the door to the commodification of babies." (Ms. Rougevin-Baville) $)^{52}$

"[Surrogate motherhood] is unfair, especially for LGBT people, because there will be those who have money and who can avail themselves of a company that will facilitate everything and others who don't have money and you won't be able to have access. So there's an economic inequality issue there." (Xavier) 
"If you're an environmentalist, you can't say that it's wrong to play around with the genetics of plants, to bring science into living things, while at the same time freeing up all these techniques that can be used commercially [on human beings].... It's obvious that there's an American-style lobby. I mean there's money behind it." (Philippe)

In addition, the calls for resistance were frequently grounded in the notion that France, with its history of defending human rights, is an exceptional place in this world and, as such, needs to resist the forces of globalization and Americanization by refusing to accept these reproductive technologies.

“There's a big difference between the United States and Europe. You live in a consumer society, which is much more developed than here, so everything that makes a profit in the United States is considered good. That's why surrogate motherhood exists over there. You can buy a child.... America is sick at this moment. The Grapes of Wrath, from Steinberg, you are in the same phase. It's a hardened country, which is deeply in crisis." (François)

Christine Boutin echoed these concerns, calling for the French to embrace their country's heritage of defending human rights and to resist the "Anglo-Saxon" neoliberal model:

The question is whether France is in the process of accepting a form of unbridled free-capitalism without rules based on the Anglo-Saxon model and rejecting its tradition of human rights... How is it possible that in France we can imagine for one instant being able to transform a woman's body into the subject of a contract, where money plays a main role? How can France take part in this new slavery that will rent out the wombs of poor women for the benefit of rich couples? And 
the child? What does he become? Rather than being the result of adult's desire, he becomes a product for consumption. ${ }^{53}$

These statements reflect a desire to present opposition to same-sex marriage, which leads to an acceptance of medically assisted procreation and surrogate motherhood, as a form of French resistance to globalization, neoliberalism, and Americanization, by asserting French exceptionalism in a world that supposedly no longer shares France's concern with human dignity. Indeed, one of the interviewees, Philippe, invoked José Bové, a French sheep farmer and head of the Conféderation paysanne (a vocal farmers union in France), who was transformed into a national hero after leading a crowd in attacking a McDonald's restaurant in 199954: "Do you know José Bové? Well, he came out against medically assisted procreation." The reference to José Bové, who is sometimes referred to as the new French Astérix (the Gallic comic book character who resists Roman imperialism and represents the quintessential French résistant), situates Philippe's opposition to procreation technologies as a form of contemporary French resistance..$^{55}$

Consequently, although in the United States it is hardly uncommon to see an overlap between opponents of same-sex marriage and defenders of neoliberalism and limited environmental regulation, in France, opposition to same-sex marriage often goes hand in hand with concerns over the effects of unbridled capitalism and environmental calls for the preservation of "human ecology." Fears of neo-liberalism and unbridled capitalism along with defenses of "human ecology" are strongly connected to an assertion of French exceptionalism in an increasingly globalized world, and offer one more example of how what is actually at stake here is the definition of Frenchness. 


\section{Lack of Religious References}

The most striking feature of the French anti-same-sex-marriage movement is the lack of religiously inspired criticism of homosexual acts per se. The website for the MPT clearly states that the group does not in any way condemn sexual acts between people of the same-sex: "The penal code forbids any discrimination based on sexual orientation. It is the pride and honor of our republic to proclaim this principle. We hate homophobia and are resolutely engaged against any form of discrimination." ${ }^{\prime 56}$ The people I interviewed echoed these sentiments:

"We don't judge homosexuals, because we aren't trying to hurt people." (Pierre)

"I don't see any problem with two men being affectionate on the street, living together, that's not a problem for me. They can do whatever they want. If they're happy, good for them!” (Julie)

My informants' statements reflect the official platform of the MPT, which does not reference religion. ${ }^{57}$ Guillaume put it simply when he said, "we absolutely do not put religion out there. Religion is a private affair." The fact that explicit religious references have been almost entirely absent in French anti-same-sex-marriage protests is not surprising given France's long history of secularism in the political sphere. Indeed, any American news article about French gay marriage that has referred to France as a "Catholic country" is a bit misleading. According to a 2007 survey, 51 percent of French people identify as Catholic, but only half of that 51 percent believe in the existence of God. ${ }^{58}$ Generally speaking, French political discourse assumes a stricter separation between church and state than political discourse in the US, based on the understanding that religion is a private affair. Today there is widespread agreement even among Catholics that religious belief is a personal matter that should play no role in political discourse. Over the course of the twentieth century, French Catholicism underwent a process that Danièle 
Hervieu-Léger refers to as “internal secularization," where Catholics' acceptance of a strict secularism in the political sphere, which began as a pragmatic accommodation to a changing society, eventually became a theological virtue. ${ }^{59}$ This explains why Philippe, who identifies as Catholic, said: "The difference is that in France we really value the separation between church and state.... In the end, I think it's an advantage for the French, because they're able to develop a line of reasoning that's much more 'atheist' so to speak, or in any case, not religious."

In recent years, the secularization of France has gone beyond the political realm to the cultural realm, a process Hervieu-Léger refers to as the "exculturation" of Catholicism. French culture continued to bear the imprint of its Catholic past long after the complete secularization of the political sphere, but today this is less and less the case. Rather than accepting beliefs produced by religious institutions, individuals are cobbling together their own belief systems, and embracing the idea that "the authenticity of one's personal spiritual path is more important than conformity with official truths. ${ }^{\circ 60}$ Even if French Catholic churches were to make explicit calls to oppose homosexual acts per se, individual parishioners might be unwilling to do so.

Many have pointed out that despite the lack of religious references in its public discourse, there actually is religious backing behind the movement, arguing that the MPT's claim not to be associated with any religion is a façade.$^{61}$ Not only is the bulk of its coordination handled by traditional Catholic groups, but so is much of its financing. Yet even if the movement's claim of being areligious serves to strategically mask its religious backing, what is important for the purposes of this article is that the effort to hide this fact demonstrates the extent to which religious references are not considered a part of legitimate public discourse in France. This is especially important, since, as David Paternotte has pointed out, the strong separation between church and state in France has not prevented the development of minority factions of radical 
Catholics, and if the MPT wanted to present itself as a moderate, rational political actor, it needed to make "a distinction with its radical fringes [including] both extreme right activists and the ultra-Catholic movement Civitas." ${ }^{2}$

Another component of the internal secularization referred to by Hervieu-Léger has been a dismissal of the supposed incompatibility between religious belief and science. This has allowed for a "theological instrumentalization of "scientific truths" "through references to anthropological, biological, or psychoanalytical ideas. ${ }^{63}$ Indeed, during the legislative discussion of the same-sex marriage law, anthropologists and psychoanalysts were invited to testify before the National Assembly. ${ }^{64}$ French psychoanalysts were divided on the question, with those opposing the law saying that it is essential for a child to encounter the sexual difference, or "asymmetry," that comes with having a mother and a father, ${ }^{65}$ while 1,500 psychoanalysts, psychologists, and psychiatrists in favor of the law signed a petition saying that there is nothing in psychoanalytical theory that can be used to oppose same-sex marriage or parenting. ${ }^{66}$ Meanwhile, my informants spoke to me about the menace of "a new anthropological order" that would be in opposition to the "natural law." 67

"As for me, my motivations are purely anthropological.... My vision of humanity is that man must be aware of his finiteness, conscious of his limits, and accept them. There is a natural law, and it's not because certain technical tricks allow you to liberate yourself from certain things, I'm thinking for example of procreation, that you can do whatever you please, no, nature exists." (Xavier) Xavier's statement points to a source of ambiguity with the use of the word "anthropological," since the word can refer either to the study of human societies (the more common definition) or to the metaphysical study of the essence of humankind (sometimes called, 
"philosophical anthropology"). ${ }^{68}$ While it is true that anthropologists of the first type testified in front of the National Assembly, when MPT activists use the term, they are almost always relying on the second definition. ${ }^{69}$ As Céline Béraud and Philippe Portier have explained, the MPT's use of "anthropological" refers to a distinction between "individuals" and "subjects." "Individuals" think of themselves as "sovereign, independent of any social or moral order," while "subjects" see themselves as existing in "an order of constraint" that is essential for any human society. ${ }^{70}$ This ambiguity allows the MPT to use a word that conveys an air of scientific objectivity, while actually making moral, even religious, judgments about the need for limits on what people should be allowed to do.

References to a "natural order" have also served to mask moral and religious ideas as near-scientific truths. As Denis Pelletier explains: "Since the beginning of the 1970s, bishops have become firm supporters of republican secularism," but this has been accompanied by "growing rigidity around the Catholic conception of "natural order." ${ }^{\text {"71 }} \mathrm{He}$ adds that "at a time when same-sex parenting is receiving the approval of a growing part of public opinion, bishops are reaffirming the biological foundation of filiation and have set an objective for themselves of deepening their teaching on sexual difference."’72

French opponents of same-sex marriage end up less likely than their American counterparts to invoke religious ideas in the public sphere. In addition, France's strong separation between the private and public spheres, especially concerning sex, means that arguments against same-sex marriage in France are unlikely to have focused on what happens in the privacy of individuals' bedrooms — perhaps not a surprise in a country where "sodomy" was legalized as early as 1791 (the first country in Europe to do so) and sexual acts in private between consenting adults, gay or straight, have been legal ever since. One outlier is the opponent of same-sex 
marriage, Christine Boutin, who referred to homosexuality as an "abomination"; yet her case also signals how far out of line this kind of speech is with acceptable political discourse, given that she was fined 5,000 euros for "public provocation to hate and violence" as a result. ${ }^{73}$

Finally, from debates over Muslim headscarves in public schools in the 1990s to the recent controversy over the "burkini," laïcité has been invoked as a means to control Islam and, as a consequence, public expression of religion is increasingly coming to mean un-French. Moreover, it might even be the case that laïcité, a value originally wielded by the left to control Catholicism, is increasingly associated with the political right through efforts to limit Muslim religious expression in public spaces. As Elisabeth Badinter explains, "besides Marine Le Pen, nobody defends laïcité any longer. On the left, the battle has been completely abandoned, except perhaps by Manuel Vals. The left has let the following equation appear: the defense of laïcité equals racism." 74 Her statement is hyperbolic, certainly, yet in this context, MPT's commitment to secular discourse is hardly surprising.

\section{Conclusion}

Each of the preceding six sections has highlighted a difference between the ways in which the movement against same-sex marriage is articulated in France and the United States. They have also shown that each of these differences points to the fact that while the argument is nominally about same-sex marriage, the definition of what it means to be French is also clearly at stake. Concern for the sanctity of filiation (as opposed to the sanctity of marriage) is related to a preoccupation with racial origins. The criticism of so-called "gender theory" stems largely from the perception that it is an American import, and thus thoroughly un-French. The need for the MPT to represent itself as a non-sectarian movement made up of folks from across the political 
spectrum is a sign of the continued influence of the French republican model and its requirement that political demands be made in universalist terms. The festive, playful protest style of the MPT represents the adoption of distinctly French protest aesthetics going back to the Situationists and actions associated with May '68. The MPT's focus on medically assisted procreation, and especially on surrogate motherhood, can be understood as a form of resistance to unbridled neoliberalism and a defense of French exceptionalism in the face of increased Americanization and globalization. And finally, the most important difference between France and the United States, the lack of religious references, stems from the idea that to be French is to embrace laïcité - a value which has become increasingly central to right-wing discourse, particularly in its criticism of Muslim religious expression in public spaces.

In the earliest days of the MPT, back in 2013, young, violent French nationalists sometimes unexpectedly showed up as the protests were winding down, creating chaos and yelling "La France aux Français" ("France for the French"), effectively bringing the anti-samesex-marriage protests to an end as the remaining MPT protestors fled. ${ }^{75}$ The MPT leadership condemned these actions and journalists sought to determine what connections might exist between the MPT and these radical nationalist groups. Yet if, as I have argued here, the concerns underlying the MPT anti-same-sex-marriage actions are actually about a definition of Frenchness, the arrival of these nationalists is not surprising. It may not have been entirely conscious, but they seem to have understood the connection.

Eric Fassin argued in his 2003 book, Liberté, égalité, sexualités, that in debates over issues of gender and sexuality, the French were often talking about something else. He pointed to unexpected connections between debates over the PACS and women's underrepresentation in politics, between debates over women's underrepresentation in politics and prostitution, between 
debates over prostitution and immigration, and between debates over sexual violence and economic inequalities, all of which became apparent to the sociological observer. ${ }^{76}$ As the case of the MPT illustrates, this was no less true in 2003 than it is today. The MPT's rhetoric and actions, which are ostensibly about same-sex marriage in France, veneer a preoccupation with the definition of Frenchness that lies just beneath the surface.

Scott Gunther, Professor of French Studies at Wellesley College, is a specialist of contemporary French culture and society. His interests include the mass media, gender and sexuality, France's role in the European Union, Franco-American relations, Franco-German relations, and comparative (French/American) law. His book, The Elastic Closet: A History of Homosexuality in France, 1942-Present (2009), examines gay politics in contemporary France with a focus on the complex relationship between French republican values and the possibilities they offer for social change.

\section{Notes}

${ }^{1}$ All of the translations from French sources into English are my own. A few short passages in this article also appeared in: Scott Gunther, "Gay Marriage Debates and Interpretative Bird Dances in France," The Huffington Post, 25 February 2013, http://www.huffingtonpost.com/scott-gunther/gay-marriage-debate-in-france_b_2762165.html, and Scott Gunther, "France and the 'American Scarecrow'," The Gay \& Lesbian Review (October 2012).

${ }^{2} \mathrm{~A}$ list of all of the associated movements can be found here: http://www.lamanifpourtous.fr/qui-sommes-nous/les-associations-partenaires/. 
${ }^{3}$ On its website, the Family Research Council lists the following issues (http://www.frc.org/Marriage-and-Family): “Abortion, Euthanasia/End of Life Issues, Stem Cells and Biotechnology, Conscience Protection, Women's Health, Marriage \& Family, Family Structure, Family Economics, Parental Rights, Human Sexuality, Education, Abstinence and Sexual Health, Homosexuality, Pornography, Religious Liberty, Religion in Public Life.” The American Family Association says it "spurs activism devoted to: Preservation of Marriage and the Family, Decency and Morality, Sanctity of Human Life, Stewardship, Media Integrity" (http://www.afa.net/who-is-afa/our-mission/). The site for Concerned Women for America says that its core issues are: Sanctity of Life ..., Defense of Family (CWA believes that marriage consists of one man and one woman. We seek to protect and support the Biblical design of marriage and the gift of children), Education (CWA supports reform of public education by returning authority to parents...), Religious Liberty ..., National Sovereignty ..., Sexual Exploitation (CWA endeavors to fight all pornography, obscenity, prostitution, and sex slavery), Support for Israel...” (http://concernedwomen.org/issues/).

4 “Vision and Mission Statements," http://www.frc.org/mission-statement (accessed 20 July 2016).

5 “Our Mission," http://www.afa.net/who-is-afa/our-mission/ (accessed 20 July 2016).

6 “Our Mission," http://concernedwomen.org/about/vision-mission/ (accessed 20 July 2016).

${ }^{7}$ The words for this word cloud come from 3,238 tweets and retweets from the Manif pour tous's twitter account (https://twitter.com/LaManifPourTous) between 1 October 2014 and 9 June 2015. The word cloud omits common French words along with all hashtags, dates, and the term "RT." ${ }^{8}$ Bruno Perreau, Queer Theory: The French Response (Stanford, CA: Stanford University Press, 2016). 
${ }^{9}$ Camille Robcis, "Liberté, Égalité, Hétérosexualité: Race and Reproduction in the French Gay Marriage Debates," Constellations: An International Journal of Critical \& Democratic Theory 22, 3 (September 2015): 447-461.

${ }^{10}$ Éric Fassin, "Same-Sex Marriage, Nation, and Race: French Political Logics and Rhetorics," Contemporary French Civilization 39, 3 (January 2014): 281-301.

${ }^{11}$ Bénédicte Lutaud, "Mariage homo: Les arguments des antis - ça m'intéresse," http://www.caminteresse.fr/economie-societe/arguments-contre-mariage-homosexuel-1155491/. ${ }^{12}$ Ibid.

${ }^{13}$ Lisa Bryant, "Frenchman Divided Over France's Gay Marriage Debate," Voice of America, 12 January 2013, http://www.voanews.com/content/frenchman_is_divided_over_gay_marriage_debate_in_france/ 1602351.html.

14 “Marriage Rate, Selected Years, 1960-2013 (per 1000 Inhabitants) YB15.png - Statistics Explained," http://ec.europa.eu/eurostat/statisticsexplained/index.php/File:Crude_marriage_rate,_selected_years,_1960\%E2\%80\%932013_(per_1 _000_inhabitants)_YB15.png; and "FastStats - Marriage and Divorce," http://www.cdc.gov/nchs/fastats/marriage-divorce.htm (accessed 19 July 2016).

${ }^{15}$ Elie Barth, "M. Le Pen se déclare favorable au mariage des homosexuels," Le Monde, 4 June 2004.

${ }^{16}$ Eric Fassin, "Order and Disorder in the Family," in The French Republic: History, Values, Debates, ed. Edward Berenson, Christophe Prochasson, and Vincent Duclert (Ithaca, NY: Cornell University Press, 2011).

${ }^{17}$ Fassin, "Same-Sex Marriage, Nation, and Race" [emphasis added]. 
${ }^{18}$ Fabrice Madouas, "Luc Chatel désavoué," Valeurs actuelles, 17 November 2011, http://www.valeursactuelles.com/societe/luc-chatel-desavoue-30325.

${ }^{19}$ Europa Terra Nostra, "La fausse rumeur de la 'théorie du genre': Explications...," AgoraVox le média citoyen, 11 July 2014, http://www.agoravox.fr/tribune-libre/article/la-fausse-rumeur-dela-theorie-du-154307; Nicolas Truong, "Qui a peur des études de genre ?” Le Monde, 11 October 2014, http://www.lemonde.fr/idees/article/2014/10/11/qui-a-peur-des-etudes-degenre_4504690_3232.html.

${ }^{20}$ Clément Guillou, "Rappel à Michel Onfray: La 'théorie du genre' n'existe pas (et l'informatique est utile)," L'Obs, 10 September 2014, http://rue89.nouvelobs.com/2014/09/10/rappel-a-michel-onfray-theorie-genre-nexistelinformatique-est-utile-254766; Karine Lambin, "II n'existe pas une ‘théorie du genre,"” BFMTV, 29 January 2014, http://www.bfmtv.com/societe/ii-nexiste-pas-une-theorie-genre698030.html? page $=3$.

${ }^{21}$ Samuel Laurent and Jonathan Parienté, “'Mariage pour tous', ce qui est faux et ce qui est flou," 29 January 2013, http://www.lemonde.fr/politique/article/2013/01/29/mariage-pour-tousce-qui-est-faux-et-ce-qui-est-flou_1823825_823448.html.

${ }^{22}$ Emmanuel de Préval was interviewed at a Manif pour tous protest by Angélique Négroni, “Manif pour tous: contre la marchandisation des bébés," Le Figaro, 5 October 2014, http://www.lefigaro.fr/actualite-france/2014/10/05/01016-20141005ARTFIG00208-contre-lamarchandisation-des-bebes.php.

${ }^{23}$ Camille Robcis, "Gender Trouble in France," 8 December 2014, https://www.jacobinmag.com/2014/12/gender-trouble-in-france/.

${ }^{24}$ Denis Pelletier, Les Catholiques en France depuis 1815 (Paris: La Découverte, 1997), 43. 
${ }^{25}$ Ibid., 44.

${ }^{26}$ Perreau, Queer Theory, 57-58.

${ }^{27}$ Eric Fassin, “L’épouvantail Américain,” Vacarme 4, 4-5 (1997): 66-68.

${ }^{28}$ Clarisse Fabre and Eric Fassin, Liberté, égalité, sexualités: actualité politique des questions sexuelles (Paris: Belfond, 2003), 26.

${ }^{29}$ In Regents of the University of California v. Bakke, the Supreme Court ruled against any affirmative action program based on quotas in 1978.

${ }^{30}$ Gunther, "France and the 'American Scarecrow'."

${ }^{31}$ Négroni, "Manif Pour Tous."

32 Julien Massillon, "Manif anti-mariage du 13: derrière Barjot, la puissance des réseaux cathos," 11 January 2013, http://yagg.com/?post_type=post\&p=59265.

${ }^{33}$ Ibid.

${ }^{34}$ Ibid.

35 Ibid.

${ }^{36}$ Scott Gunther, The Elastic Closet: A History of Homosexuality in France, 1942-Present (New York: Palgrave, 2009), 87.

${ }^{37}$ Massillon, "Manif anti-mariage du 13."

${ }^{38}$ Robcis, “Liberté, Égalité, Hétérosexualité."

${ }^{39}$ Nicolas Truong, “Vers Un 'printemps' anti-Mai 68 ?” 25 May 2013, http://www.lemonde.fr/idees/article/2013/05/23/vers-un-printemps-anti-mai68_3416608_3232.html. 
${ }^{40}$ Stephen Colbert, "France and the Mali Conflict," The Colbert Report (Comedy Central, 24 January 2013), http://www.cc.com/video-clips/xaaxud/the-colbert-report-france---the-maliconflict.

${ }^{41}$ The Hommen are a group of young men who oppose same-sex marriage using the motto "radicalement du côté des enfants" (radically on the side of children). Their protest style, which includes slogans written on their bare chests, mimics the style of the feminist group, Femen. "Hommen Officiel," accessed 26 August 2016, http://hommen-officiel.tumblr.com/.

42 John Oliver, "Gaywatch: International Edition," The Daily Show (Comedy Central, 13 June 2013), http://www.cc.com/video-clips/01pn0y/the-daily-show-with-jon-stewart-gaywatch--international-edition.

${ }^{43}$ Claire Tancons, "Occupy Wall Street: Carnival Against Capital? Carnivalesque as Protest Sensibility," in The Political Aesthetics of Global Protest: The Arab Spring and Beyond, ed. Pnina Werbner, Martin Webb, and Kathryn Spellman-Poots (Edinburgh: Edinburgh University Press, 2014), 297.

${ }^{44}$ Truong, "Vers un 'printemps' anti-Mai 68?"

${ }^{45}$ Raoul Vaneigem, The Revolution of Everyday Life (London: Rebel Press, 2001), 110-111.

${ }^{46}$ Céline Emmerechts, "Nuit debout techno: le dancefloor politique de la place de la République,” Trax, 12 April 2016, http://en.traxmag.com/fr/article/32834-report-nuit-debouttechno-le-dancefloor-politique-de-la-place-de-la-republique.

${ }^{47}$ Céline Béraud and Philippe Portier, Métamorphoses catholiques: Acteurs, enjeux et mobilisations depuis le mariage pour tous (Paris: Maison des sciences de l'Homme, 2015), 107. 48 "Les affiches officielles," La manif pour tous, 27 September 2014, http://www.lamanifpourtous.fr/actualites/preparez-vos-affiches-pour-le-5-octobre/. 
${ }^{49}$ Pope Benedict XVI, "Christmas Greetings to the Members of the Roman Curia and Prelature," 22 December 2008, https://w2.vatican.va/content/benedictxvi/en/speeches/2008/december/documents/hf_ben-xvi_spe_20081222_curia-romana.html. See also Mary Anne Case, “After Gender the Destruction of Man? The Vatican’s Nightmare Vision of the 'Gender Agenda' for Law," Pace Law Review 31, 3 (June 2011) and Éric Fassin, “Les 'forêts tropicales' du mariage hétérosexuel: Loi naturelle et lois de la nature dans la théologie actuelle du Vatican," Revue d'éthique et de théologie morale 261, HS (2010): 201-222.

${ }^{50}$ Chantal Delsol, 'Les orwelliens, ou la naissance d'une gauche conservatrice, par Chantal Delsol," Le Monde.fr, 23 May 2013, sec. Idées, http://www.lemonde.fr/idees/article/2013/05/23/les-orwelliens-ou-la-naissance-d-une-gaucheconservatrice_3416546_3232.html.

${ }^{51}$ Michael Stambolis-Ruhstorfer and Josselin Tricou, "Resisting 'gender Theory' in France: A Fulcrum for Religious Action in a Secular Society," in Anti-Gender Campaigns in Europe: Mobilizing against Equality, ed. Roman Kuhar and David Paternotte (London: Rowman \& Littlefield International, 2017), 84.

52 Négroni, "Manif pour tous."

${ }^{53}$ Christine Boutin, "Si nous adoptons le mariage homosexuel, nous ne serons plus la patrie des droits de l'Homme," Atlantico.fr, http://www.atlantico.fr/decryptage/adoptons-mariagehomosexuel-ne-serons-plus-patrie-droits-homme-christine-boutin-626864.html (accessed 29 October 2015).

54 Suzanne Daley, “French Farmer Is Sentenced to Jail for Attack on McDonald's - The New York Times," New York Times, 14 September 2000, 
http://www.nytimes.com/2000/09/14/world/french-farmer-is-sentenced-to-jail-for-attack-onmcdonald-s.html.

${ }^{55}$ Tony Karon, “Why Courts Don’t Deter France's Anti-McDonald's 'Astérix’ - TIME,” Time, 15 February 2001, http://content.time.com/time/world/article/0,8599,99592,00.html.

56 “Comprendre l'essentiel," http://www.lamanifpourtous.fr/comprendre/comprendre-lessentiel/. (accessed 20 July 2016).

57 “Comprendre l'essentiel”; “Ce que nous voulons,” http://www.lamanifpourtous.fr/quisommes-nous/notre-message/ (accessed 20 July 2016).

58 “La France est-elle encore catholique?" Le Monde des religions, 1 January 2007, http://www.lemondedesreligions.fr/archives/2007/01/01/la-france-est-elle-encorecatholique,8494603.php.

${ }^{59}$ Danièle Hervieu-Léger, Catholicisme, la fin d'un monde (Paris: Bayard, 2003), 74.

${ }^{60}$ Danièle Hervieu-Léger, “Aujourd'hui, chacun bricole sa propre spiritualité,” Le spectacle du monde, 11 April 2010, http://www.lespectacledumonde.fr/index.php?option=com_content $\&$ view $=$ article $\&$ catid $=29 \% 3 \mathrm{~A}$ dossier\&id $=285 \% 3$ Adossier566\&Itemid $=59$.

${ }^{61}$ For an analysis of these influences, see Perreau, Queer Theory, 37-40.

${ }^{62}$ David Paternotte, "The Anti-Gender Movement in Comparative Perspective," in Anti-Gender Campaigns in Europe: Mobilizing Against Equality (London: Rowman \& Littlefield International, 2017), 264.

${ }^{63}$ Hervieu-Léger, Catholicisme, 246. 
${ }^{64}$ Marie Boëton, “Les psychiatres auditionnés à l'Assemblée sur le mariage homosexuel - La Croix," 16 November 2012, http://www.la-croix.com/France/Les-psychiatres-auditionnes-a-lAssemblee-sur-le-mariage-homosexuel-2012-11-16-876697.

${ }^{65}$ Gaëlle Dupont, "Vif débat chez les psys sur l'homoparentalité,” 25 September 2012, http://www.lemonde.fr/societe/article/2012/09/25/vif-debat-chez-les-psys-sur-1homoparentalite_1765372_3224.html. For more on the testimonies of psychoanalysts before the National Assembly, see Vincent Bourseul, "Les normes sexuelles, la psychanalyse et le 'mariage pour tous," Cahiers de psychologie clinique 2, 45 (2015): 95-109.

${ }^{66}$ Elisabeth Roudinesco, "Intervention à l'Assemblée nationale," ProChoix, Les opposants au mariage pour tous 57 (April 2013), 38. The petition can be found online at http://www.petitionpublique.fr/PeticaoVer.aspx?pi=P2012N30808. 67 "Ce que nous voulons."

${ }^{68}$ Céline Béraud and Philippe Portier, Métamorphoses catholiques: Acteurs, enjeux et mobilisations depuis le mariage pour tous (Paris: Maison des sciences de l'Homme, 2015), 113. ${ }^{69}$ As Eric Fassin has pointed out, this was not the case during debates over the PACS, when anthropological arguments against it were made using the first, more common definition of anthropology, with opponents arguing that opposite-sex couples were the norm across all human cultures. Fassin, "Same-Sex Marriage, Nation, and Race:."

${ }^{70}$ Céline Béraud and Philippe Portier, Métamorphoses catholiques: Acteurs, enjeux et mobilisations depuis le mariage pour tous (Paris: Maison des sciences de l'Homme, 2015), 113.

${ }^{71}$ Denis Pelletier, "Les évêques de France et la République de l'intime (1968-2005)," in Catholicisme en tensions, by Céline Béraud, Frédéric Gugelot, and Isabelle Saint-Martin (Paris: Éditions de l'EHESS, 2012), 179. 
72 Ibid., 188.

73 “Christine Boutin condamnée à 5000 euros d'amende pour avoir qualifié l'homosexualité d'abomination'," Le Monde, 18 December 2015, http://www.lemonde.fr/famille-vieprivee/article/2015/12/18/christine-boutin-condamnee-a-5-000-euros-d-amende-pour-avoirqualifie-1-homosexualite-d-abomination_4834809_1654468.html.

${ }^{74}$ Elisabeth Badinter, "Un peu de kantisme dans notre société serait bienvenu," Le Monde des religions, 28 September 2011, http://www.lemondedesreligions.fr/entretiens/elisabeth-badinterun-peu-de-kantisme-dans-notre-societe-serait-bienvenu-28-09-2011-1894_111.php.

75 “Mariage gay: Qui sont les mouvements d'extrême-droite qui perturbent les manifestations? L’Express,' 21 April 2013, http://www.lexpress.fr/actualite/societe/mariage-gay-qui-sont-lesmouvements-d-extreme-droite-qui-perturbent-les-manifestations_1242605.html; "Violences lors de la 'manif pour tous': ce que l’on sait - 27 Mai 2013 - L’Obs,’ 27 May 2013, http://tempsreel.nouvelobs.com/politique/mariage-gay-lesbienne/20130527.OBS0756/violenceslors-de-la-manif-pour-tous-ce-que-1-on-sait.html.

${ }^{76}$ Fabre and Fassin, Liberté, Égalité, Sexualités. 